慶應義塾大学学術情報リポジトリ

Keio Associated Repository of Academic resouces

\begin{tabular}{|c|l|}
\hline Title & $\begin{array}{l}\text { Expression and characterization of recombinant pyruvate kinase from Toxoplasma gondii } \\
\text { tachyzoites }\end{array}$ \\
\hline Sub Title & トキソプラズマ急増虫体の遺伝子組換えピルビン酸キナーゼの発現と解析 \\
\hline Author & 前田, 卓哉(Maeda, Takuya) \\
\hline Publisher & 慶應医学会 \\
\hline Publication year & 2004 \\
\hline Jtitle & 慶應医学 (Journal of the Keio Medical Society). Vol.81, No.2 (2004. 6),p.30- \\
\hline JaLC DOI & \\
\hline Abstract & \\
\hline Notes & 号外 \\
\hline Genre & Journal Article \\
\hline URL & https://koara.lib.keio.ac.jp/xoonips/modules/xoonips/detail.php?koara_id=AN00069296-2004060 \\
& 2-0030 \\
\hline
\end{tabular}

慶應義塾大学学術情報リポジトリ(KOARA)に掲載されているコンテンッの著作権は、それぞれの著作者、学会または出版社/発行者に帰属し、その権利は著作権法によって 保護されています。引用にあたっては、著作権法を遵守してご利用ください。

The copyrights of content available on the KeiO Associated Repository of Academic resources (KOARA) belong to the respective authors, academic societies, or publishers/issuers, and these rights are protected by the Japanese Copyright Act. When quoting the content, please follow the Japanese copyright act. 


\section{Expression and characterization of recombinant pyruvate kinase from Toxoplasma gondii tachyzoites \\ （トキソプラズマ急増虫体の遺伝子組換えピルビン酸キナーゼの発現と解析）}

\section{前田卓 哉}

\section{内容の要旨}

トキソプラズマ (Toxoplasma gondii) の急増虫体（tachyzoite）は エネルギー源を主に解糖系に依存していると考えられているが、そ の活性調節機構を含めた詳細については、未だ体系的には理解され ていない。特に解糖系の律速酵素として知られるへキンキナーゼ、 ホスホフルクトキナーゼおよびピルビン酸キナーゼのうち、へキy キナーゼおよびホスホフルクトキナーゼは非調節酵素として存在し ていることが既に報告されている。一方、原虫の粗抽出酵素を用い た検討では、ピルビン酸キナーゼがアロステリック酵素として存在 し、解糖系の調節酵素として重要な役割を果たしていると報告され ているが、実際の調節メカニズムについては不明な点が多く残され ている。今回、トキソプラズマのピルビン酸キナーゼ遺伝子をク ローニングし、組換え酵素を作製して、その酵素学的性質と解糖系 における役割について検討を加えた。

はじめに、ESTのデータベースをもとに、T.gondii cDNAライブラ リーから全長2,207塩基のピルビン酸キナーゼの遺伝子をクローニン グし、組換え酵素を作製した。酵素学的性状としては、(1)至適 $\mathrm{pH}$ 7.0 近傍にもち、(2)活性にはカリウムイオンが必須であり、2 価の陽 イオン、特にマンガンによって著明に活性化を受けた。さらに(3)基 質であるホスホエノールピルビン酸に対してはアロステリックに作 用する一方、従来から活性化物質として知られるフルクトース 1 , 6ービスリン酸によっては影響を受けず、へキソキナーゼの反応生 成物であるグルコース 6 -リン酸の存在下においてのみ酵素は特異 的に活性化された。さらに、この特徴的な性質は酵素のアミノ酸配 列にも反映しており、酵素の活性部位を含む領域では種を超えて非 常によく配列が保存されていたが、フルクトース 1，6-ビスリン 酸などのリガンドが結合する活性調整領域の相同性は低く、トキy プラズマでは極めて特異なアミノ酸配列を有していた。

トキソプラズマではホスホフルクトキナーゼが非調節酵素であ り、第一の律速酵素として知られるへキソキナーゼは、反応生成物 であるグルコース 6 -リン酸によってフィードバック阻害を受けな いが、活性が低く律速酵素として機能することが報告されている。 そのうえ、グルコース 6 -リン酸によってピルビン酸キナーゼが活 性調節を受けており、グルコース 6 -リン酸を介するへキソキナー ゼーピルビン酸キナーゼの系が、解糖系の流れを調節する重要な役 割を果たしていることが示唆された。この特徽的なメカニズムにつ いては、トキソプラズマの細胞内寄生現象と関連するか否か、その 生物学的意義については今後の検討が必要である。

\section{論文審査の要旨}

細胞内寄生原虫であるトキソプラズマは、そのエネルギー産生の 多くを解糖系に依存しているが、未だ解糖系の調節のメカニズムに ついての詳細な検討は行なわれていない。本研究は、多くの細胞で 解糖系の律速酵素の一つであるピルビン酸キナーゼについて、その 重要性に鑑み、トキソプラズマ急增虫体（tachyzoite）から遺伝子を クローニングし、組換え蛋白を作製して、その酵素学的解析を試み たものである。解析の結果、トキソプラズマの酵素はグルコース 6リン酸による活性調節を受けるという極めて特異な性質を明らかに した。またこの所見に基づいて、グルコース 6-リン酸結合部とおも われる部分のアミノ酸配列について詳細に検討を加えた。審査では 組換えピルビン酸キナーゼが四量体を形成することについて、その 解析方法の詳細が問われ、組換え蛋白とnativeの蛋白について、ゲル ろ過法とSDS-PAGE法を行ない、四量体を形成すると推定した旨が 回答されたが、さらに超遠心法等を併用してより詳細に分子量を検 討する必要があること、さらに、どのような結合様式で四量体を形 成するのかも併せて検討する必要があることが指摘された。また、 細胞内において、ピルビン酸キナーゼが糖付加などの修飾を受ける 可能性について質問がなされ、組換え蛋白とnativeの蛋白について分 子量に差がみられないことから、糖付加などの修飾を受けていない と考えて矛盾しない旨が回答された。さらに、二価の陽イオンによ る酵素の活性化効果に関連し、酵素蛋白にintrinsicに結合している可 能性のある金属イオンの有無、酵素反応系でのイオン濃度の調整方 法の詳細が問われ、組換え蛋白を予めEDTAにてキレート処理後、陽 イオンが添加された旨が回答された。また、組換え蛋白の至適 $\mathrm{pH}$ ついても質問がなされ、pH7.0近傍で最も高い活性が得られ、酸性側 では比較的低いpHまで活性が得られる一方、アルカリ性側では、 $\mathrm{pH}$ が8.0を超えると急速に活性が低下する事が答えられた。さらに、解 糖系のバイパス経路であるペントースリン酸回路について、その系 の存在と活性調節メカニズムについては、グルコース 6-リン酸の解 糖系における役割について解析する上で非常に重要であり、さら に、宿主と異なる性質をもつこのピルビン酸キナーゼが、抗トキソ プラズマ薬の開発ターゲットになりうるかどうかを検討する上で も、今後検討するべき課題であるとの指摘がなされた。

以上、本研究は、グルコース 6-リン酸による活性調節の生理的意 義の解明など、今後更に検討を継続する余地を残しているものの、 トキソプラズマにおける解糖系の律速酵素の一つであるピルビン酸 キナーゼの解析を組換え蛋白を用いて行ない、従来の報告にはない 新たな活性調節メカニズムを明らかにしたものであり、原虫感染症 研究の上で有意義な研究と評価された。

論文審查担当者 主査 熱帯医学・寄生虫学 竹内 勤 微生物学・免疫学 小安 重夫病理学 岡田 保典

学力確認担当者 : 医化学 末松 誠

審査委員長 : 小安 重夫 